\title{
Population Density and Weed Infestation in ORganic No-Tillage CoRn CROPPING System UNDER Different SOIL COVERS ${ }^{1}$
}

\author{
Densidade Populacional e Infestação de Plantas Daninhas no Plantio Direto Orgânico de Milho- \\ Verde sobre Diferentes Coberturas de Solo
}

\author{
FAVARATO, L.F. ${ }^{2}$, GALVÃO, J.C.C. ${ }^{3}$, SOUZA, J.L. ${ }^{2}$, GUARÇONI, R.C. ${ }^{2}$, SOUZA, C.M. ${ }^{3}$, and \\ CUNHA, D.N. ${ }^{3}$
}

\begin{abstract}
Currently, one of the biggest challenges faced by organic no-tillage farming is weed control. Thus, the use of cropping practices that help in the control of weeds is extremely important. The objective of this study was to evaluate population density and level of weed infestation in an organic no-tillage corn cropping system under different soil covers. The experiment was conducted in a randomized block design with six repetitions and five treatments, consisting of three soil covers in an organic no-tillage system, and an organic and a conventional system, both without soil cover. The treatments with soil cover used a grass species represented by the black oat, a leguminous species represented by the white lupine, and intercropping between both species. Corn was sown with spacing of $1.0 \mathrm{~m}$ between rows and $0.20 \mathrm{~m}$ between plants, using the commercial hybrid AG 1051. Infestation in corn was evaluated at stages V5 and V10, and weed density was evaluated at stage V5. The use of black oat straw alone or intercropped with white lupine, in the organic no-tillage corn cropping system, reduced the percentage of weed infestation and absolute weed density. Managementintensive systems and systems without soil cover showed higher relative densities for species Oxalis spp., Galinsoga quadriradiata and Stachys arvensis. The species Cyperus rotundus showed the highest relative density on organic no-tillage corn cropping systems. Black oat straw in the organic no-tillage cropping system limited the productive potential of corn.
\end{abstract}

Keywords: Avena strigosa, Lupinus albus, straw, organic farming.

RESUMO - Atualmente, um dos maiores entraves do sistema plantio direto orgânico é o controle de plantas daninhas. Desse modo, o uso de práticas culturais que auxiliem no controle dessas plantas torna-se de extrema relevância. Objetivou-se avaliar a densidade populacional e o nivel de infestação de plantas daninhas no plantio direto orgânico de milho-verde sob diferentes coberturas de solo. $O$ experimento foi conduzido no delineamento de blocos casualizados, com seis repetições e cinco tratamentos, constituidos por três coberturas de solo no sistema plantio direto orgânico e dois sistemas sem cobertura, sendo um orgânico e um convencional. Para os tratamentos com cobertura de solo foi utilizada uma espécie graminea representada pela aveia-preta e uma espécie leguminosa representada pelo tremoço-branco, bem como o consórcio com as ambas espécies. A semeadura do milho para produção de espigas verdes foi feita no espaçamento de 1,0 m entre linhas e 0,20 $\mathrm{m}$ entre plantas, utilizando o híbrido comercial AG 1051. Foram realizadas avaliações de infestação nos estádios V5 e V10 do milho e de densidade de plantas daninhas no estádio V5. O uso de palha de aveia-preta solteira ou em consórcio com tremoço-branco, no sistema plantio direto orgânico de milho-verde, proporcionou redução do percentual de infestação e densidade absoluta de plantas daninhas. Os sistemas com manejo intensivo e sem cobertura de solo apresentaram maior densidade relativa das espécies Oxalis spp., Galinsoga quadriradiata e Stachys arvensis. A espécie Cyperus rotundus apresentou-se com maior densidade absoluta e relativa nos sistemas com plantio direto orgânico de milho-verde.

Palavras-chave: Avena strigosa, Lupinus albus, palhada, sistema orgânico.

Recebido para publicação em 14.3.2014 e aprovado em 22.7.2014.

2 Instituto Capixaba de Pesquisa, Assistência Técnica e Extensão Rural, Domingos Martins-ES, Brasil, <luiz.favarato@incaper.es.gov.br>; ${ }^{3}$ Universidade Federal de Viçosa, Viçosa-MG, Brasil. 


\section{INTRODUCTION}

The organic no-tillage cropping system typically has a lower level of mechanical disturbance compared to conventional tillage. It is a feasible alternative to soil management because it enables the maintenance of crop residues, thus providing benefits such as increased organic matter.

However, it is difficult to implement this system as regards control of weeds and soil cover, as there are no desiccants recommended for organic agriculture, and post-emergence herbicides cannot be used, either. Thus, growing plants that produce husk in the offseason is crucial for weed control (Corrêa et al., 2011).

The use of mulch protects the soil from solar radiation, dissipates energy from the impact of raindrops, reduces evaporation of water and increases the efficiency of nutrient recycling (Mateus et al., 2004). In addition, it is an alternative to weed control (Vidal \& Bauman, 1996; Oliveira et al., 2001; Severino $\&$ Christoffoleti, 2001). This control can occur physically by impairing light incidence and reducing soil temperature range (Severino \& Chistoffoleti, 2001); biologically by increasing the population of microorganisms that can infect weed diaspores (Radosevich et al., 1997); and by releasing allelochemicals that inhibit plant growth (Trezzi \&Vidal, 2004; Souza et al., 2006).

The effect of mulch on weeds has been widely studied. Trezzi \& Vidal (2004) evaluated the physical and allelopathic effects and differential suppression of weeds by genotypes of sorghum and millet. The results, conditional on volume of straw, reached $74 \%$ reduction in total dry matter of weeds. Several other studies have shown the effect of mulch on weeds (Gravena et al., 2004; Erasmo et al., 2004; Mateus et al., 2004; Noce et al., 2008).

Fancelli \& Dourado Neto (2000) reported that the straw of jack bean (Canavalia ensiformis) inhibited the development of purple nut sedge (Cyperus rotundus); the straw of velvet bean (Mucuna aterrima) hindered the growth of purple nut sedge and beggar-ticks (Bidens pilosa); turnip (Raphanus sativus) reduced the initial growth of corn; Johnson grass (Sorghum halepense) reduced soybean production; black oat (Avena strigosa) decreased the population of Alexandergrass (Brachiaria plantaginea); and ryegrass (Lolium multiflorum) reduced the population of prickly sida (Sida spp.).

The use of vegetation cover adapted to edaphic and climatic conditions may reduce weed infestation, providing a more complete soil cover and changing soil physicochemical properties (Skóra Neto, 1993; Severino \& Cristoffoleti, 2001).

Thus, knowledge of the likely effects of regularly using cover crops allows them to be used in crop rotation or intercropping, in the context of integrated weed management.

This study aimed to assess population density and level of weed infestation in organic no-tillage corn cropping systems under different soil covers.

\section{MATERIAL AND METHODS}

The study was conducted from July 2013 to January 2014, in the experimental station of INCAPER in Domingos Martins-ES, Brazil $\left(20^{\circ} 22^{\prime} 16.91^{\prime \prime S}\right.$ and $41^{\circ} 03^{\prime} 41.83^{\prime \prime} \mathrm{W}$, at an altitude of $950 \mathrm{~m}$. In this region, average maximum temperatures in the warmer months range between 26.7 and $27.8{ }^{\circ} \mathrm{C}$ and the average minimum temperatures in the cooler months range between 8.5 and $9.4^{\circ} \mathrm{C}$. Annual average rainfall is $1,800 \mathrm{~mm}$.

The experiment was arranged in a randomized complete block design with six replications and five treatments, totaling 30 experimental plots measuring $6.0 \times 4.0 \mathrm{~m}$ and with a total area of $24 \mathrm{~m}^{2}$. The treatments consisted of three types of soil cover in the organic no-tillage cropping system and two systems with soil disturbance but without soil cover: an organic one and a conventional one. The treatments with soil cover used a grass species, represented by black oat (Avena strigosa), a legume species, represented by white lupine (Lupinus albus) and intercropping between both species.

The cover crops were sown on July 10, 2013, in rows spaced at $0.33 \mathrm{~m}$, with the following seed density in single cropping systems: 144 grams per plot for black oat $\left(60 \mathrm{~kg} \mathrm{ha}^{-1}\right)$ and 204 grams per plot for white 
lupine $\left(85 \mathrm{~kg} \mathrm{ha}^{-1}\right)$. In the intercropping system, seeding rates and the amount of seeds were reduced by half because plantings were done in alternating rows. Sprinkler irrigation was performed as needed.

At the flowering stage, 90 days after sowing, cover crops were mown with a backpack mower, and evenly distributed over the soil surface. After the biomass was settled on the soil surface, organic fertilization was performed by organic compound application at a dose of $1.5 \mathrm{~kg} \mathrm{~m}^{-1}$ (dry weight), evenly distributed by broadcasting on all organically managed experimental plots, prior to the sowing of corn for the production of green ears. These were the characteristics of the compound: N, P, K, Ca and Mg; 1,5, 0,7, $1,7,1,8$ and 0.3 dag $\mathrm{kg}^{-1}$, respectively; $\mathrm{Zn}, \mathrm{Fe}$, $\mathrm{Mn}, \mathrm{Cu}$ and $\mathrm{B}: 100,15.100,281,92$ and $32 \mathrm{mg} \mathrm{dm}^{-1}$; CO, 33\%; and $\mathrm{C} / \mathrm{N}, 13$. In plots with conventional tillage without soil cover, fertilization for corn cropping was performed with $800 \mathrm{~kg} \mathrm{ha}^{-1}$ of the fertilizer (4-14-8 rate). In the V5 development stage of corn, topdressing fertilization was performed with $100 \mathrm{~kg} \mathrm{ha}^{-1}$ of $\mathrm{N}$ by broadcast application of ammonium sulfate over the plots.

The AG-1051 fit corn hybrid cultivar was sown on October 18, 2013, with the aid of manual seeder, spaced at $1.00 \mathrm{~m}$ between rows and $0.20 \mathrm{~m}$ between plants at the rate of two seeds per hole and subsequently thinned to one plant per hole. As a result, there were six rows and 120 plants per plot, equivalent to a population of 50,000 plants ha- ${ }^{-1}$, without use of additional topdressing fertilization for plots with organic cropping. The useful area of the plot was formed by four central rows, excluding $0.50 \mathrm{~m}$ at each end.

Evaluations were performed of the soil cover resulting from weed infestation at stages V5 and V10 of corn, and manual weeding was done after the first evaluation. The samples were collected by means of digital photographs taken with a Sony Cyber -shot DSC-W690 digital camera (16.1 megapixels), placed $1.00 \mathrm{~m}$ above the ground in six different regions of each plot. The percentage of weed infestation was measured with the computational system SISCOB ${ }^{\circledR}$, developed by Embrapa Agricultural Instrumentation, which showed the percentage of soil cover provided by weeds in each digital photograph. The data collected were transformed by the function and underwent analysis of variance and the ScottKnott test with a significance level of $\mathrm{p}>0.05$.

Population density was assessed at the V5 stage of corn, with the aid of a square measuring $0.50 \mathrm{~m}$ on the sides, randomly placed in the area of each plot. The process was repeated four times. At each sampling, the species were identified and counted, and the absolute and relative densities of each weed species were determined in the different treatments.

For assessment of the similarity of the weed community among treatments, a presence/absence matrix was designed for the species and a dendrogram was subsequently created among the studied systems using the software SAEG (Ribeiro Júnior, 2001). The dendrogram was prepared with the mean Euclidean distance to measure distances between two points, and the method of average linkage hierarchical clustering was used.

At the R3 stage of corn, all the ears of the useful area of the plot were harvested and evaluated for total and marketable yield of unkusked ears.Unhusked ears are considered to be marketable when their length exceeds $0.15 \mathrm{~m}$, according to Moreira et al. (2010), and their average diameter is $0.04 \mathrm{~m}$, and they are ripe and free from injuries caused by insect pests and diseases. Data were subjected to analysis of variance and the means were compared by the Scott-Knott test at 5\% probability.

\section{RESULTS AND DISCUSSION}

Dry matter production of black oat and white lupine covers and intercropping with both species were, respectively, 5,695, 6,280 and $7.133 \mathrm{~kg} \mathrm{ha}^{-1}$. These values are close to $6.000 \mathrm{~kg} \mathrm{ha}^{-1}$ as proposed by Alvarenga et al. (2001), who consider such amount enough for good soil cover and, therefore, for maintaining no-tillage cropping.

Table 1 shows that the lack of soil cover provided greater weed infestation in both the conventional and the organic systems in both assessment periods. The lack of soil cover not only allows more light but also enables 
Table 1 - Percentage of soil cover provided by weed infestation at 15 and 45 days after emergence of corn (DAE) in different cropping systems

\begin{tabular}{|c|c|c|}
\hline \multirow{2}{*}{ Treatment } & \multicolumn{2}{|c|}{ Weed infestation (\%) } \\
\cline { 2 - 3 } & V5 & V10 \\
\hline CS & $0.87^{1 /}(59) \mathrm{d}$ & $0.57(29) \mathrm{c}$ \\
\hline OS & $0.42(17) \mathrm{c}$ & $0.58(30) \mathrm{c}$ \\
\hline $\mathrm{G}$ & $0.20(4) \mathrm{a}$ & $0.29(8) \mathrm{a}$ \\
\hline $\mathrm{L}$ & $0.30(9) \mathrm{b}$ & $0.43(18) \mathrm{b}$ \\
\hline $\mathrm{G}+\mathrm{L}$ & $0.20(4) \mathrm{a}$ & $0.33(11) \mathrm{a}$ \\
\hline Mean & $0.39(18.6)$ & $0.44(19.2)$ \\
\hline CV 2 / $(\%)$ & 12.24 & 16.68 \\
\hline
\end{tabular}

${ }^{1 /}$ Values transformed for the function $\mathrm{y}=\arcsin [\sqrt{ }(\mathrm{x} / 100)]$. Means followed by the same letter in the column do not differ by the Scott-Knott test at 5\% probability. ${ }^{2 /}$ Coefficient of variation. CS - conventional system without straw; OS - organic system without straw; G - Organic NT cropping with grass straw; L organic NT cropping with legume straw; G + L -Organic NT cropping with grass + legume straw.

more alternating temperatures, which can stimulate the germination of many species (Souza et al., 2011). Trezzi \& Vidal (2004) observed a reduction of $41 \%$ infestation and $74 \%$ of total dry matter of weeds, comparing the areas covered with crops to the uncovered control.

Theisen et al. (2000), working with germination of weeds in bare soil and covered soil, observed that covered soils had lower incidence of $B$. plantaginea, because of reduced quantity and modified quality of the light that reaches the seeds of this species.
In organic no-tillage corn cropping systems, the presence of the grass species in the composition of husk provided greater weed control in both assessment periods (Table 1). This result can be explained by the use of black oat as a grass species. This species shows allelopathic action attributed to its ability to exude scopoletin. Scopoletin is a byproduct from the class of coumarins and has inhibitory effect on plant root growth (Ducca et al., 2008). According to Almeida et al. (2008), oat exudes that metabolite in the soil through the roots. Jacob \& Fleck (2000) found that there is a relationship between the exuded scopoletin and the allelopathic potential of oat.

Vaz de Melo et al. (2007) found that organic no-tillage corn cropping practices showed good results in weed management when oat straw was used as soil cover. Penha et al. (2010) found that black oat fosters a reduction of $90 \%$ or more of soil coverage by weeds.

In the experimental area, 14 weed species were identified. They belong to nine botanical families, and most of them are represented by the family Asteraceae (Table 2).

The dendrogram in Figure 1 suggests that there are three homogeneous groups: group A - formed by conventional system without husk and organic system without husk (systems 1 and 2); Group B - formed by organic no-tillage (NT) cropping system with straw from grass species and organic NT cropping with straw

Table 2 - Scientific names, common names, botanical families and classes, of weed species collected in the experimental area

\begin{tabular}{|l|l|l|l|}
\hline \multicolumn{1}{|c|}{ Scientific names } & \multicolumn{1}{|c|}{ Common name } & \multicolumn{1}{c|}{ Class } \\
\hline Amaranthus spp. & Pigweed & Amaranthaceae & Dicotyledon \\
\hline Artemisia absinthium & Absinthium & Asteraceae & Dicotyledon \\
\hline Bidens pilosa & Beggar-ticks & Asteraceae & Dicotyledon \\
\hline Commelina benghalensis & Benghal dayflower & Commelinaceae & Monocotyledon \\
\hline Cynodon dactylon & Bermuda grass & Poaceae & Monocotyledon \\
\hline Cyperus rotundus & Purple nut sedge & Cyperaceae & Monocotyledon \\
\hline Digitaria sanguinalis & Hairy crabgrass & Poaceae & Monocotyledon \\
\hline Eleusine indica & Crowfoot grass & Poaceae & Monocotyledon \\
\hline Euphorbia heterophylla & Milkweed & Euphorbiaceae & Dicotyledon \\
\hline Galinsoga quadriradiata & Fringed quickweed & Asteraceae & Dicotyledon \\
\hline Oxalis spp. & Shamrock & Oxalidaceae & Dicotyledon \\
\hline Rumex obtusifolius & Broad-leaved dock & Polygonaceae & Dicotyledon \\
\hline Sonchus oleraceus & Common sowthistle & Asteraceae & Dicotyledon \\
\hline Stachys arvensis & Staggerweed & Lamiaceae & Dicotyledon \\
\hline
\end{tabular}




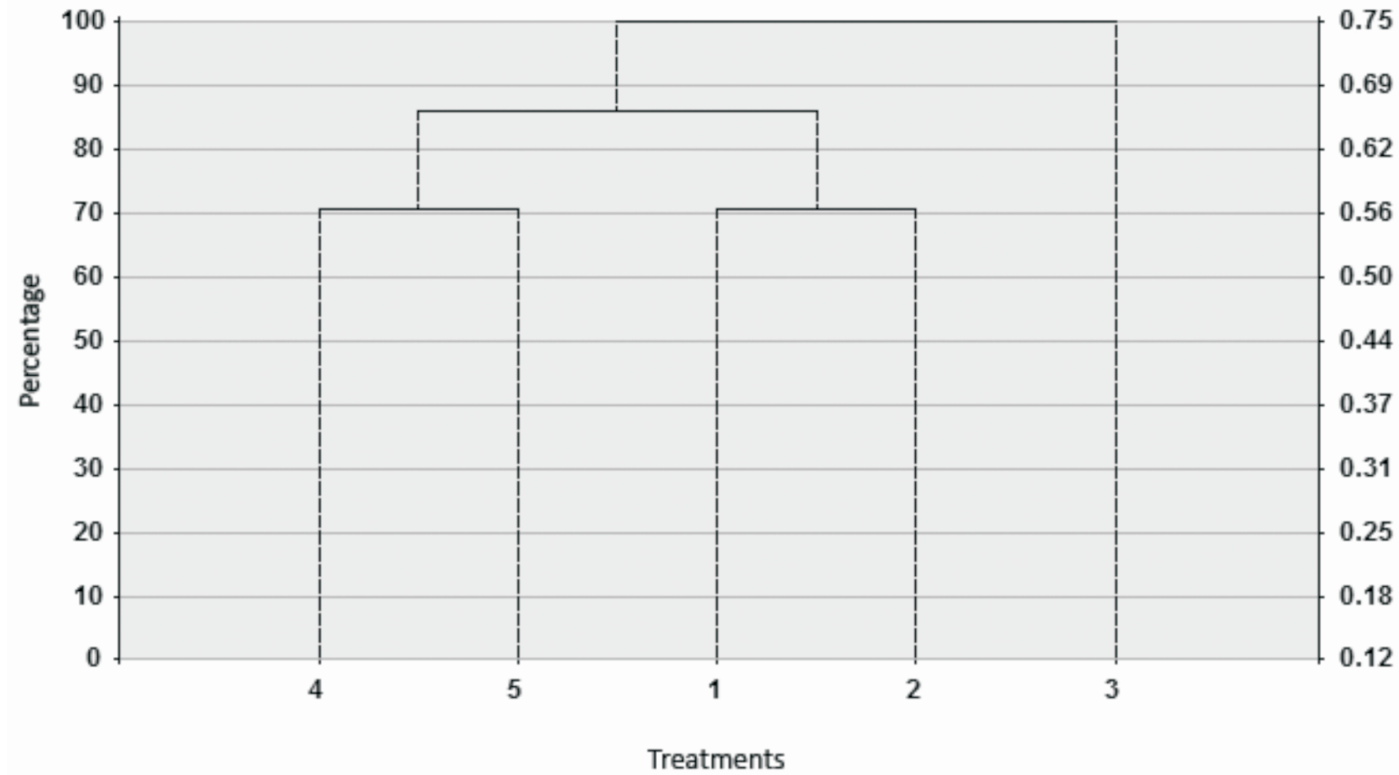

뭄

Figure 1 - Dendrogram between systems treatments: 1) conventional system without straw, 2) organic system without straw, 3) organic NT cropping with grass straw, 4) organic NT cropping with legume straw and 5) organic NT cropping with grass + legume straw.

from grass + leguminous species (systems 4 and 5) and group C - formed by organic NT cropping with straw from grass species (system 3).

The formation of group A, which consisted of organic and conventional systems without straw, can be associated with the management used in both systems, with the absence of straw on the soil surface and continued soil tillage, favoring the presence of the same species. Different soil management systems condition the seeds to soil microenvironments, because of changes in their physico-chemical properties and the conditions of the soil surface (Mulugueta \& Stoltenberg, 1997). According to Carvalho \& Pitelli (1992), similarity indices are not related only to soils or distance between areas, but they may be associated with forms of management adopted in these areas. These changes may influence the development and germination of weeds.

The second group comprises organic NT corn cropping on the straw of white lupine and the intercropping between lupine and black oat. The appearance of this group can be explained by the presence of white lupine in the composition of straw; because it is a legume species, it has low $\mathrm{C} / \mathrm{N}$ ratio as a result of biological $\mathrm{N}$ fixation, which causes the rapid degradation of straw (Teixeira et al., 2009), with greater soil exposure to light and thermal variation, in addition to quick release of nutrients (Rosolem et al., 2003). These conditions may have favored the appearance of the same weed species in both cropping systems.

The fact that NT cropping system on the straw of a grass species is singled out in an separate group may be related to the characteristics of black oat straw, since this species has a high $\mathrm{C} / \mathrm{N}$ ratio with soil mineral nitrogen being held back by microorganisms that require it for the synthesis of their cellular compounds, and it may even disappear from the soil during the maximum growth period of the microbial community. During this period, depending on the nutritional requirements of the weed species, its growth and development may be inhibited due to temporary shortage of soil mineral nitrogen. Cardoso (1992) stated that mineral nitrogen reappears only in the decline phase of the microbial community, and it is mineralized from dead microbial cells by living organisms. The allelopathic action of black oat should also be noted. It is attributed to the ability of black oat to exude scopoletin, which has an inhibitory effect on plant root growth (Ducca et al., 2008). 
With absolute density of 1,169 plants $\mathrm{m}^{-2}$, the conventional system without straw showed the highest number of specimen per unit area, followed by the organic system without straw, with 438 plants $\mathrm{m}^{-2}$. This difference can be attributed to the soil seed bank, because the conventional system had not only higher absolute density but also the greatest number of species. In organic no-tillage cropping systems with soil cover, there was a reduction in the absolute density of weeds, with a total of 96,159 and 108 plants $\mathrm{m}^{-2}$ for soil cover with black oat, white lupine and the intercropping between both species, respectively (Table 3). These data corroborate those shown in Table 1 and indicate that the use of straw on the soil reduces both weed infestation and weed density in the cultivated area.

Table 3 shows higher relative density of species Oxalis spp., Galinsoga quadriradiata and Stachys arvensis both in the conventional and the organic systems without straw. The highest relative density of these species may be related to the type of management adopted in the systems, because there is intense soil disturbance in both of them, favoring asexual propagation of the species Oxalis spp.; moreover, the lack of straw on the surface and intensive soil management provide suitable conditions for establishing the species G. quadriradiata and S. arvensis, since these species have seminiferous propagation and depend on light to germinate (Klein \& Felippe, 1991).

Despite the intensive soil management with continuous tillage in uncovered systems, there is low relative density of Cyperus rotundus (Tabela 3); according to Godoy et al. (1995) and Ferreira et al. (2000), using conventional tillage favors the propagation and establishment of this species due to dormancybreaking caused by division of the tuber sequence and the elimination of apical dominance exerted by the distal tubercle. This reduced density of $C$. rotundus can be attributed to interspecific competition from species with higher density.

In organic no-tillage systems, regardless of the straws used, there is higher relative density for C. rotundus (Table 3). This result was also observed by Vaz de Melo et al. (2007) in organic no-tillage corn cropping. The species $C$. rotundus is one of the most difficult to be controlled, but its management in traditional tillage with glyphosate desiccation is more efficient than in the organic system, in which the use of straw was inefficient. According to Freitas et al. 1997), glyphosate is

Table 3 - Absolute and relative densities of weed species found in different cropping systems

\begin{tabular}{|c|c|c|c|c|c|c|c|c|c|c|}
\hline \multirow{2}{*}{ Species } & \multicolumn{5}{|c|}{ Absolute density (plants $\mathrm{m}^{-2}$ ) } & \multicolumn{5}{|c|}{ Relative density (\%) } \\
\hline & $\mathrm{CS}$ & OS & $\mathrm{G}$ & $\mathrm{L}$ & $\mathrm{G}+\mathrm{L}$ & CS & OS & $\mathrm{G}$ & $\mathrm{L}$ & $\mathrm{G}+\mathrm{L}$ \\
\hline Amaranthus spp. & 13 & 17 & - & 19 & 21 & 1.1 & 3.9 & - & 11.9 & 19.4 \\
\hline Artemisia absinthium & - & - & 10 & 12 & 4 & - & - & 10.4 & 7.5 & 3.7 \\
\hline Bidens pilosa & 11 & 19 & - & 4 & - & 0.9 & 4.3 & - & 2.5 & - \\
\hline Commelina benghalensis & - & - & 10 & 7 & 16 & - & - & 10.4 & 4.4 & 14.8 \\
\hline Cynodon dactylon & 13 & - & 6 & - & 3 & 1.1 & - & 6.3 & - & 2.8 \\
\hline Cyperus rotundus & 163 & 16 & 47 & 40 & 25 & 13.9 & 3.7 & 49.0 & 25.2 & 23.1 \\
\hline Digitaria sanguinalis & 15 & - & - & 10 & 5 & 1.3 & - & - & 6.3 & 4.6 \\
\hline Eleusine indica & 29 & - & - & 3 & 2 & 2.5 & - & - & 1.9 & 1.9 \\
\hline Euphorbia heterophylla & - & 12 & - & 15 & 3 & - & 2.7 & - & 9.4 & 2.8 \\
\hline Galinsoga quadriradiata & 200 & 125 & - & 18 & 5 & 17.1 & 28.5 & - & 11.3 & 4.6 \\
\hline Oxalis spp. & 355 & 225 & 21 & 21 & 20 & 30.4 & 51.4 & 21.9 & 13.2 & 18.5 \\
\hline Rumex obtusifolius & 19 & - & - & - & 4 & 1.6 & - & - & - & 3.7 \\
\hline Sonchus oleraceus & 47 & 5 & 2 & 10 & - & 4.0 & 1.1 & 2.1 & 6.3 & - \\
\hline Stachys arvensis & 304 & 19 & - & - & - & 26.0 & 4.3 & - & - & - \\
\hline Total & 1169 & 438 & 96 & 159 & 108 & & & & & \\
\hline
\end{tabular}

CS - conventional system without straw; OS - organic system without straw; G - Organic NT cropping with grass straw; L - NT cropping with organic legume straw; $\mathrm{G}+\mathrm{L}-$ Organic NT cropping with grass + legume straw. 
effective at controlling purple nut sedge, because it can translocate to the tubers next to the basal bulb, which has resulted in a significant reduction in regrowth after glyphosate application. When rakes and hoes are used for weed control in organic production systems, the infestation of Cyperaceae species can be a problem because of the increased propagation by dividing the tubers, as observed by Jakelaitis et al. (2003) and Machado et al. (2005).

Corn plants grown organically under organic NT cropping system on black oat straw had lower values for total and marketable yields of unhusked ears (Table 4). This behavior can be attributed to the high $\mathrm{C} / \mathrm{N}$ ratio of oat residues, which holds back much of the soil $\mathrm{N}$ by the action of microorganisms which decompose waste, thus reducing the availability of $\mathrm{N}$ in the soil and, consequently, for corn (Silva et al., 2007).

It should be stressed that, although the treatment with NT cropping on grass straw, represented by black oat in the present study, resulted in lesser corn yield, it has the benefit of suppressing weed growth (Table 1), given its high $\mathrm{C} / \mathrm{N}$ ratio, which provides longer maintenance on the soil.

The use of black oat straw alone or intercropped with white lupine, in organic notillage corn cropping, caused a reduction in the infestation percentage and absolute density of weeds. Intensive management systems with

Table 4 - Means of TYUE - total yield of unhusked ears $\left(\mathrm{kg} \mathrm{ha}^{-1}\right)$, YMUE - yield of marketable unhusked ears $\left(\mathrm{kg} \mathrm{ha}^{-1}\right)$

\begin{tabular}{|c|c|c|}
\hline Treatment & TYUE $\left(\mathrm{kg} \mathrm{ha}^{-1}\right)$ & YMUE $\left(\mathrm{kg} \mathrm{ha}^{-1}\right)$ \\
\hline $\mathrm{CS}$ & $10,946 \mathrm{a}$ & $9,668 \mathrm{a}$ \\
\hline $\mathrm{OS}$ & $12,006 \mathrm{a}$ & $10,914 \mathrm{a}$ \\
\hline $\mathrm{G}$ & $9,324 \mathrm{~b}$ & $7,703 \mathrm{~b}$ \\
\hline $\mathrm{L}$ & $11,230 \mathrm{a}$ & $9,863 \mathrm{a}$ \\
\hline $\mathrm{G}+\mathrm{L}$ & $10,569 \mathrm{a}$ & $9,438 \mathrm{a}$ \\
\hline Mean & 10,815 & 9,517 \\
\hline $\left.\mathrm{CV}^{2} / \%\right)$ & 8.29 & 10.88 \\
\hline
\end{tabular}

${ }^{1 /}$ Means followed by the same letter in the rows do not differ by the Scott-Knott test at $5 \%$ probability. ${ }^{2 /}$ Coefficient of variation. CS - conventional system without straw; OS - organic system without straw; G - Organic NT cropping with straw grass; L organic NT cropping with legume straw; G + L - Organic NT cropping with grass + legume straw. and without soil cover had higher relative density of species Oxalis spp., G. quadriradiata and $S$. arvensis. The species $C$. rotundus showed greater absolute and relative density for organic no-tillage corn cropping. Black oat straw in organic no-tillage cropping limited the productive potential of corn.

\section{LITERATURE CITED}

ALMEIDA, G. D. et al. Estresse oxidativo em células vegetais mediante aleloquímicos. R. Fac. Nac. Agron., v. 61, n. 1, p. 4237-4247, 2008.

ALVARENGA, R. C. et al. Plantas de cobertura de solo para sistema plantio direto. Inf. Agropec., v. 22, n. 1, p. 25-36, 2001.

CARDOSO, E. J. B. N. Efeito da matéria orgânica na biologia do solo. In: GUERRINI, I. A.; THEODORO, L. (Ed.). ENCONTRO SOBRE MATÉRIA ORGÂNICA DO SOLO: PROBLEMAS E SOLUÇÕES, 1992, Botucatu. Anais... Botucatu: FCA/UNESP, 1992. p. 37-62.

CARVALHO, S. L.; PITELLI, R. A. Comportamento e análise fitossociológica das principais espécies de plantas daninhas de pastagens da região de Selvia, MS. Planta Daninha, v. 10, n. $1 / 2$, p. 25-32, 1992.

CORRÊA, M. L. P. et al. Dinâmica populacional de plantas daninhas na cultura do milho em função de adubação e manejo. R. Ci. Agron., v. 42, n. 2, p. 354-363, 2011.

DUCCA, F.; ZONETTI, P. C. Efeito Alelopático do extrato Aquoso de Aveia Preta (Avena strigosa Schheb.) na Germinação e desenvolvimento de soja (Glycine max L. merril). R. Agronegócios Meio Amb., v. 1, n. 1, p. 101-109, 2008.

ERASMO, E. A. L. et al. Potencial de espécies utilizadas como adubo verde no manejo integrado de plantas daninhas. Planta Daninha, v. 22, n. 3, p. 337-342, 2004.

FANCELLI, A. L.; DOURADO-NETO, D. Produção de milho. Guaíba: Agropecuária, 2000. 360 p.

FERREIRA, F. A. et al. Manejo integrado de plantas daninhas em hortaliças. In: ZAMBOLIM, L. (Ed.). MANEJO INTEGRADO DE DOENÇAS, PRAGAS E PLANTAS DANINHAS, 2000, Viçosa, MG. Palestras... Viçosa, MG: 2000. p. 365-372.

FREITAS, R. S. et al. Efeitos do flazassulfuron e do glyphosate em aplicações única e sequencial sobre o controle da tiririca (Cyperus rotundus). R. Ceres, v. 44, n. 256, p. 597-603, 1997. 
GODOY, G.; VEGA, J.; PITTY, A. El tipo de labranza afecta la flora y la distribución vertical del banco de semillas de malezas. Ceiba, v. 36, n. 2, p. 217-229, 1995.

GRAVENA, R. et al. Controle de plantas daninhas através da palha de cana-de-açúcar associada à mistura dos herbicidas trifloxysulfuron sodium + ametrina. Planta Daninha, v. 22, n. 3, p. 419-427, 2004.

JACOB, U. S.; FLECK, N. G. Avaliação do potencial alelopático de genótipos de aveia no início do ciclo. Pesq. Agropec. Bras., v. 35, n. 1, p. 11-19, 2000.

JAKELAITIS, A. I. et al. Dinâmica populacional de plantas daninhas sob diferentes sistemas de manejo nas culturas de milho e feijão. Planta Daninha, v. 21, n. 1, p. 71 79, 2003.

KLEIN, A.; FELIPPE, G. M. Efeito da luz na germinação de sementes de ervas invasoras. Pesq. Agropec. Bras., v. 26, n. 7, p. 955-966, 1991.

MACHADO, A. F. L. et al. Population dynamic of weeds in no-tillage and conventional crop systems. J. Environ. Sci. Health Part B - Pestic. Food Agric., v. B40, p. 119-128, 2005.

MOREIRA, J. N. et al. Effect of detasseling on baby corn, green ear and grain yield of two maize hybrids. Hortic. Bras., v. 28, n. 4 , p. $406-411,2010$.

MULUGUETA, D.; STOLTENBERG, D. E. Increase weed emergence and seed bank depletion by soil disturbance in notillage systems. Weed Sci., v. 45, n.2, p. 120-126, 1997.

MATEUS, G. P.; CRUSCIOL, C. A. C.; NEGRISOLI, E. Palhada do sorgo de guiné gigante no estabelecimento de plantas daninhas em área de plantio direto. Pesq. Agropec. Bras., v. 39, n. 6, p. 539-542, 2004.

NOCE, M. A. et al. Influência da palhada de gramíneas forrageiras sobre o desenvolvimento da planta de milho e das plantas daninhas. R. Bras. Milho Sorgo, v. 7, n. 3, p. 265-278, 2008.

OLIVEIRA, M. R. et al. Efeito da palha e da mistura atrazine e metolachlor no controle de plantas daninhas na cultura do milho em sistema de plantio direto. Pesq. Agropec. Bras., v. 36, n. 1 , p. $37-41,2001$.

PENHA, L. A. O. et al. Consórcios de aveia, linho e ervilha para a supressão de plantas daninhas. In: CONGRESSO BRASILEIRO DA CIÊNCIA DAS PLANTAS DANINHAS, 27., 2010, Ribeirão Preto. Anais... Ribeirão Preto: 2010. p. 2052-2055.

RADOSEVICH, S. et al. Weed ecology. 2.ed. New York: Wiley, 1997. 588 p.
RIBEIRO JÚNIOR., J. I. Análises estatísticas no SAEG (Sistema para análises estatísticas). Viçosa, MG: Universidade Federal de Viçosa, 2001. 301 p.

ROSOLEM, C. A.; CALONEGO, J. C.; FOLONI, J. S. S. Lixiviação de potássio da palhada de espécies de cobertura de solo de acordo com a quantidade de chuva aplicada. R. Bras. Ci. Solo, v. 27, n. 2, p. 355-362, 2003.

SEVERINO, F. J.; CHRISTOFFOLETI, P. J. Efeitos de quantidades de fitomassa de adubos verdes na supressão de plantas daninhas. Planta Daninha, v. 19, n. 2, p. 223-228, 2001.

SKÓRA NETO, F. Controle de plantas daninhas através de coberturas verdes consorciadas com milho. Pesq. Agropec. Bras., v. 28, n. 10, p. 1165-1171, 1993.

SILVA, A. A. et al. Sistemas de coberturas de solo no inverno e seus efeitos sobre o rendimento de grãos do milho em sucessão. Ci. Rural, v. 37, n. 4, p. 928-935, 2007.

SOUZA, L. S. et al. Efeito alelopático de capim braquiária (Brachiaria decumbens) sobre o crescimento inicial de sete espécies de plantas cultivadas. Planta Daninha, v. 24, n. 4, p. $657-668,2006$.

SOUZA, M. C. et al. Efeito da época sobre a emergência de Sida rhombifolia e Solanum viarum em diferentes profundidades de semeadura. R. Ceres, v. 58, n. 6 ,

p. 749-754, 2011.

TEIXEIRA, C. M. et al. Decomposição e liberação de nutrientes das palhadas de milheto e milheto + crotalária no plantio direto do feijoeiro. Acta Sci. Agron., v. 31, n. 4, p. $647653,2009$.

THEISEN, G.; VIDAL, R. A.; FLECK, N. G. Redução da infestação de Brachiaria plantaginea em soja pela cobertura do solo com palha de aveia preta. Pesq. Agropec. Bras., v. 35, n. 4, p. 753-756, 2000.

TREZZI, M. M.; VIDAL, R. A. Potencial de utilização de cobertura vegetal de sorgo e milheto na supressão de plantas daninhas em condição de campo: II - Efeitos da cobertura morta. Planta Daninha, v. 22, n. 1, p. 1-10, 2004.

VAZ DE MELO, A. I. et al. Dinâmica populacional de plantas daninhas em cultivo de milho-verde nos sistemas orgânico e tradicional. Planta Daninha, v. 25, n. 3, p. 521-527, 2007.

VIDAL, R. A.; BAUMAN, T. T. Surface wheat (Triticum aestivum) residues, giant foxtail (Setaria faberi), and soybean (Glycine max) yield. Weed Sci., v. 44, n. 5, p. 939-943, 1996. 